Article

\title{
The Digital Exclusion of Vulnerable Children: Challenge for Sustainability Issues in Czech Social Work Practice
}

\author{
Soňa Kalenda * and Ivana Kowaliková \\ Faculty of Social Studies, University of Ostrava, 70900 Ostrava, Czech Republic; ivana.kowalikova@osu.cz \\ * Correspondence: sona.kalenda@osu.cz; Tel.: +420553463205
}

Received: 17 September 2020; Accepted: 26 November 2020; Published: 28 November 2020

\begin{abstract}
The aims of this study are (1) to draw attention to the digital exclusion of vulnerable children as a systemic (socio-ecological) problem that is gaining momentum during emergencies; (2) to reflect the subjectively perceived readiness of social workers as one of the actors in the system, whose task is to contribute to the mitigation of risks arising from digital exclusion of the target group and to ensure the sustainability development of society; (3) from the position of the target group, to reflect the situation of their digital literacy and thus exclusion; and (4) to make recommendations to public policy makers and social workers to mitigate these risks and to promote sustainability. We draw on the socio-ecological model of social work which views a person in the context of their environment. The aim of the research was to analyze the use of information and communication technologies (ICTs) in social work with vulnerable children and their families and to detect system deficits contributing to digital exclusion. Based on a questionnaire survey $(\mathrm{N}=105)$, interviews with representatives of the target group $(N=20)$, and expert interviews $(N=4)$, both the main shortcomings in the digital skills of employees and the needs of the target group were identified and systemic measures were proposed.
\end{abstract}

Keywords: digital exclusion; ICT; social work

\section{Introduction}

This study broadens the existing knowledge and empirical findings about digital exclusion (abbreviated as e-exclusion) in social sciences, especially in the field of social work with vulnerable children and their families. The text brings original empirical findings highlighting the need to support resilience and prevention of e-exclusion of vulnerable children and their families. At the same time, it provides arguments for public policy makers in addressing e-exclusion and in promoting social sustainability. The originality and contribution of our study goes beyond the current research into the concept of social exclusion in social work, extending it to the concept of e-exclusion. Hämäläinen and Matikainen [1] pointed to the problems of social exclusion as a relationship between an individual's life course and society. In this context, they emphasized sustainability at (1) the economic level, (2) the social level, and (3) the spatial level as a mechanism contributing to social stability and thus to social inclusion. According to Hämäläinen and Matikainen [1], a holistic approach involving all three levels is important in addressing the social exclusion of young people. We also emphasize this fact in our study when we perceive that the prevention of e-exclusion contributes to sustainability at the economic, social, and spatial levels (which includes, among other things, the virtual environment). A holistic approach may prevent the growing polarization in society if it is based on support in education, employment, and citizenship, which can take place using digital technologies. 
Social sustainability is often discussed in terms of social capital, social inclusion, or social exclusion [2] and is a relevant approach for the target group of vulnerable children. Social sustainability seeks to address risks in solving social problems, but in practice, there are a number of pitfalls [3]. Therefore, the authors propose a conceptual framework of social sustainability (CFSS), which consists of four interconnected concepts with specific functions: (1) justice in the sense of lower alienation in society; (2) safety as protection and security in vulnerable situations; (3) sustainable urban forms as achieving urban sustainability and managing the risks of specifics of urban space; and (4) eco-prosumption leading to community efforts of individuals in society. The conceptual framework of social sustainability seeks to strengthen the protection of all people, regardless of color, origin, or socioeconomic status. This framework aims to understand social sustainability as an integration of social, economic, and environmental aspects. In the context of the abovementioned, it should be noted that research in the field of social work usually focuses on social and economics sustainability. In accordance with the abovementioned and regarding social sustainability, we primarily focus on the social world, which also includes economic aspects (the nonhuman world in the form of ecological and urban aspects is not examined in depth). In accordance with Eizenberg and Jabareen [3], we understand social sustainability as socially oriented procedures, the aim of which is to solve social problems, or as an attempt to address the risks in solving social problems (in this case, resulting from e-exclusion).

Information and communication technologies (hereinafter "ICTs") are "a diverse set of technological tools and resources used to transmit, store, create, share, or exchange information. These technological tools and resources include computers, the Internet (websites, blogs, and emails), live broadcasting technologies (radio, television, and webcasting), recorded broadcasting technologies (podcasting, audio and video players, and storage devices), and telephony (fixed or mobile, satellite, visio/video-conferencing, etc)" [4] play an increasingly important role in social interactions. On the one hand, they facilitate and accelerate interpersonal communication, thus proving the validity of the thesis of time acceleration in modern and late modern society [5-7]. On the other hand, they place increased demands on their users' digital competencies that determine their digital literacy $[8,9]$. ICTs become ubiquitous in the public and private sectors represented by national and multinational companies, in which they are "usurping" more and more space. In the public sector, they are used by the state administration and self-government authorities (the so-called e-government), NGOs (Non-Governmental Organizations), and other organizations providing public services in education, health care, social services, etc. In the 21st century, we can hardly find a segment in developed countries without them. ICTs simplify everyday life in many ways. On the other hand, they can also become a source of social inequalities and their reproduction [10]. Based on these inequalities, groups of people being at risk of the so-called e-exclusion can be found in society. We define this as exclusion from participation in the normal functioning of society due to a deficit in the availability of ICTs (no matter whether it is their physical unavailability or the ability to deal with them). This creates a "gap" between people to whom the so-called new technologies are available and those to whom they are not. E-exclusion is considered a dimension of social exclusion [11] and, thus, a subject of social work. Research of the Czech society has shown that senior groups $[8,12]$ and children $[8,13,14]$ living in the so-called disadvantaged social environment are among the groups of people most at risk of e-exclusion and subsequently social exclusion. In the presented study, we focus on the target group of vulnerable children and their families (according to $\S 6$ of Act No. 359/1999 Coll., On Social and Legal Protection of Children) [15] that makes use of the social activation services for families with children (according to $\S 65$ of Act No. 108/2006 Coll., On Social Services) for whom a threat of e-exclusion fully manifested itself in the COVID-19 (coronavirus disease 2019) pandemic emergency period. "Social activation services for families with children (hereinafter "SAS") are a field of outpatient services provided to a family with a child whose development is endangered due to the effects of a long-term crisis social situation which the parents cannot overcome on their own without help and where there are other risks to the child's development". [16]. The mission of the service is to provide support to disadvantaged families with a child or children in unfavorable or 
crisis social situations, especially if there is a risk that these conditions could result in a threat to the child's development and family integrity. In cooperation with the clients of the service, the service strives to maintain coexistence of members of these families and the healthy development of children in the conditions of a functional family [17]. Given this, e-exclusion of vulnerable children is becoming a legitimate problem in social work which must be faced and solved using adequate approaches. Its urgency grows at a time of system instability disrupted by external interventions, for example, in the form of a pandemic.

Pursuant to Articles 5 and 6 of Constitutional Act No. 110/1998 Coll., On the Security of the Czech Republic [18], the government of the Czech Republic declared a state of emergency for the territory of the Czech Republic on 12 March 2020 for a period of 30 days (with a possible further extension, which actually happened). At the same time, the government adopted other crisis measures, which had, among other things, an impact on school attendance and the provision of social services. Teaching and providing SAS had to move immediately into the online environment. SAS social workers were not prepared for such a situation and thus faced many problems. The two most pressing were (1) insufficient equipment of functional technology on the part of social service users and (2) low digital literacy of users (sometimes in combination with not entirely sufficient digital skills of social workers). In the presented article, we draw on the socio-ecological paradigm in social work [19-21]. This paradigm focuses on people in the context of their environment and mutual interactions. The aim of social work is to maintain a balance between humans and the environment: to support the development, growth, and adaptive capacity of people; to remove barriers in the environment; and to improve the ability of the environment to respond adequately to people's needs.

In the context of socio-ecological practice, human interactions with their environment become a source of social inequalities. The aim of social work is to help balance these inequalities and to maintain social stability. Only through solidarity and social responsibility can the social system be sustainable in the long run [22]. Stable systems then cope better with environmental disasters or pandemics, which we now observe in connection with the COVID-19 pandemic. At the same time, we are responding to The Grand Challenges for Social Work of the American Academy of Social Work and Social Welfare [23], which formulated the following topics: 1. maximize productive and meaningful activity throughout life, 2. ensure all youth get a good and healthy start, 3. reduce isolation and loneliness, 4. stop family violence, 5. end homelessness, 6. create greater healthy equity, 7. safely reduce our incarcerated population, 8. strengthen financial security, 9. end racial injustice, 10. strengthen social responses to environmental changes, 11. reverse extreme inequality, and 12. harness digital technology for social good. In connection with the abovementioned call, the topic of e-exclusion of vulnerable children is directly related to topics $2-4,6$, $8,9,11$, and 12 and follows up on topics $1,5,7$, and 10 . We can say that it is a cross-cutting theme that deserves the attention of public policy makers, social workers, and the general public.

The use of ICTs in social work has not been paid attention in the Czech environment until recently. Unlike in the field of education, where the government adopted the Digital Education Strategy until 2020 [8] in 2014, the use of ICTs in the field of social work has not been institutionalized in any way. The use of ICTs in social work with disadvantaged families and children was described, for example, by Vondrová [13]. Also, in 2016-2017, Recmanová and Vávrová [14] carried out research focused on information and communication technologies in social work interventions with vulnerable children and their families. Based on interviews with 25 social workers of social activation services for families with children and social workers of the department of social and legal protection of children, the topic of e-exclusion was considered very important by the respondents. It has been found that e-exclusion poses a real threat to children from socially disadvantaged families, and as such, it requires a systemic solution. These families face problems in particular when trying to get various types of information (e.g., in electronic student books at schools or information for patients at the doctors) and have problems with the use of e-government or in communication with various institutions. To respond to these problems and to help service users cope with them are new challenges for social workers. Otherwise, other forms of inequality may be exacerbated by low digital literacy [24]. 
Unlike the Czech Republic, research in other countries on the topic of e-exclusion has a longer tradition. We can draw attention to the work of Deursen and Dijk [25], who examined the use of communication technologies in the Netherlands, specifically among the target groups of people with low education and people with disabilities. As follows from research of the Czech population, too, low education is one of the basic predictors of limited use of the online environment [8,9] and exacerbates e-exclusion. As for social work, Elswick's study [26] may be mentioned, too. It addresses, among other things, the issue of accessibility or barriers to the use of ICTs by clients of social work, where social workers themselves may become one of the barriers [27]. With regard to the abovementioned facts, we included in our research not only the target group of vulnerable children and their families but also especially the group of social workers working in the field of social and legal protection of children. ICTs serve social workers as a tool to support the digital inclusion of clients (among other things). However, digital literacy of the clients is low and social workers are concerned about exacerbating the clients' digital exclusion. Social workers identified problem areas in the area of digital exclusion, such as electricity shortage; lack of ICT PCs and mobile phones/smartphones); inability to master ICTs technically; and inability to use ICTs to search, sort, and evaluate information and to communicate or create one's own content [28].

\section{Materials and Methods}

The research issue is as follows: During the COVID-19 pandemic, the digital gap between vulnerable children and their peers got wider in the Czech Republic. Schooling took place online from home, and children from socially and economically disadvantaged background often had limited access to the Internet and hardware devices (computers, tablets, smartphones, etc.). This situation caused an increased demand for support and facilitation from social workers in the use of ICTs. This problem became particularly evident in de-industrialized cities, such as Ostrava, which has the highest number of so-called socially excluded localities, and at the same time, it was also one of the regions most affected by the COVID-19 virus [29].

The aim of the research was to analyze the use of ICTs in Czech social work with vulnerable children and their families, finding out (1) how social workers subjectively perceived digital literacy and how the use of ICTs in social work interventions in times of emergency related to the COVID-19 pandemic was reflected, and (2) how the users of social services living in one de-industrialized city (Ostrava) reflected on this situation.

The main research question was as follows: What is the situation like in the use of ICTs in Czech social work with vulnerable children? Partial research questions were as follows: (1) How do social workers working with the given target group perceive their digital skills? (2) How do SAS users in one de-industrialized city (Ostrava) evaluate their digital skills in relation to the situation during the emergency? (3) How do experts from SAS assess the use of ICTs in the emergency related to the COVID-19 pandemic?

The research design was as follows: mixed research with elements of a case study using the following data collection techniques.

(1) An online questionnaire survey $(\mathrm{N}=105)$ was used to examine the access of social workers to individual ICTs, the use of individual programs, the importance of individual programs, and the subjective evaluation of the user skills of individual programs (see Appendix A). All SAS providers registered in the central Register of Social Service Providers [30] (a total of 249 SASs), managed by the Ministry of Labour and Social Affairs (MLSA), were contacted by e-mail. The application for participation in the research contained information on the objectives of the research and the method of handling the obtained data as well as a link to an online questionnaire and an entry password. The online questionnaire was published for 3 months on the portal www.survio.com, from October 2019 to December 2019. Due to a low involvement of social workers in the research, a second call was sent to the contact e-mails of the organizations. According to the data available as of 31 December 2018 [31], SAS employed a total of 792 social workers, 434 workers in social services and 29 workers in 
other special positions. If we relate the number of fully completed questionnaires to the number of Czech SAS social workers, we can state that about $13 \%$ of people from the basic sample participated in the research.

(2) Individual and group semi-structured interviews with users of social services $(\mathrm{N}=20)$ focused on evaluating access to ICTs and the Internet, the importance of individual programs, and the subjective evaluation of their user skills in individual programs, including identification of needs in ICT education (see Appendix B). These were carried out with parents and possibly children from 20 families using social activation services in the city of Ostrava, where experimental verification has been carried out focused on the development of digital competencies of socially and economically disadvantaged families living in de-industrialized cities. This was launched at the time of the emergency measures related to COVID-19 and including, among other things, lending tablets with mobile data to these families. This experimental verification has still been worked on, so it is not the subject of the present study. The families were selected for research through an institution (a social activation service for families with children operating in the city of Ostrava).

(3) Expert semi-structured interviews $(\mathrm{N}=4)$ with the heads of social services for the target group (from regions with a higher incidence of COVID-19: two from the capital city of Prague, one from the city of Ostrava, and one from the Zlin Region) aimed at managing the situation during the emergency (see Appendix C). These were selected for research on the basis of a deliberate selection through an institution (socially activation service for families with children).

As part of the research, all ethical rules of social science research were observed. The informants were involved in the research on a voluntary basis, and they could change their decision at any time during the research. The nature of the online questionnaire guarantees anonymity. In addition, interviews with minors were always conducted in the presence of a parent or other legal representatives, and the level of participation of children was left to their discretion. Parents, as legal guardians, gave researchers their written consent to participate in the research on their own behalf and on behalf of their minor children (see Appendix D). The statements of the informants were recorded or written down, and the recordings were deleted immediately after being transcribed. All statements were anonymized. The obtained data have been treated in accordance with Act No. 110/2019 Coll., On the Processing of Personal Data [32], which incorporates the relevant regulations of the European Union.

The validity of the acquired facts was supported thanks to the triangulation of data collection techniques and informants.

\section{Results}

\subsection{The Quantitative Part of the Research}

Using a questionnaire survey $(\mathrm{N}=105)$, we examined the access of social workers to individual types of ICT, the use of individual programs, the importance of individual programs, and the subjective evaluation of the user skills of individual programs.

A total of 105 respondents $(100 \%)$ were included in the analysis, for which we used MS Excel. In terms of gender distribution in this group, the proportion of women was greater-100 (95\%) - compared to men-5 (5\%). The greater proportion of women working in social services is explained by Elichová [33], among others, who calls it a feminized profession. In terms of age distribution, our group included 39 workers (37\%) in the age category of $18-30$ years, $51(49 \%)$ in the age category of $31-45$ years, and 15 (14\%) in the age category of 46-60 years. Based on $\S 110$ of Act No. 108/2006 Coll., On Social Services, we found that 73 (70\%) respondents in our sample had a university degree, $22(20 \%)$ had a higher vocational education, and $10(10 \%)$ passed an accredited social worker course. The respondents also answered in which social service they worked. From the two options offered, we found that according to the type of social service, there were $89(85 \%)$ workers of the social activation service for families with children (hereinafter "SAS") and $16(15 \%)$ workers of the shelter home for parents with children (hereinafter " $\mathrm{SH}^{\prime}$ ). Due to the low number of involved 
SH employees, in the following analysis, we present the results for both groups together. In terms of the distribution of respondents according to the length of practice in social work for their entire career, it turned out that most of them $49(47 \%)$ did not work in social services for more than 5 years. Furthermore, the respondents stated that $29(27 \%)$ worked in social services for 6 to 10 years and 27 $(26 \%)$ of respondents stated that they worked in social services for more than 11 years. In terms of the distribution of respondents according to the length of practice in social service where they currently work, we found that $78(74 \%)$ respondents worked in the addressed SASs or SHs for a maximum of 5 years, 17 (16\%) worked for 6 to 10 years, and only $10(10 \%)$ worked in social services for more than 11 years. For clarity, we present the sociodemographic characteristics of the respondents in a table in Appendix E.

Among the interviewed social workers of selected social services for vulnerable children, we found out what ITCs they had access to in their work, which is shown in Figure 1.

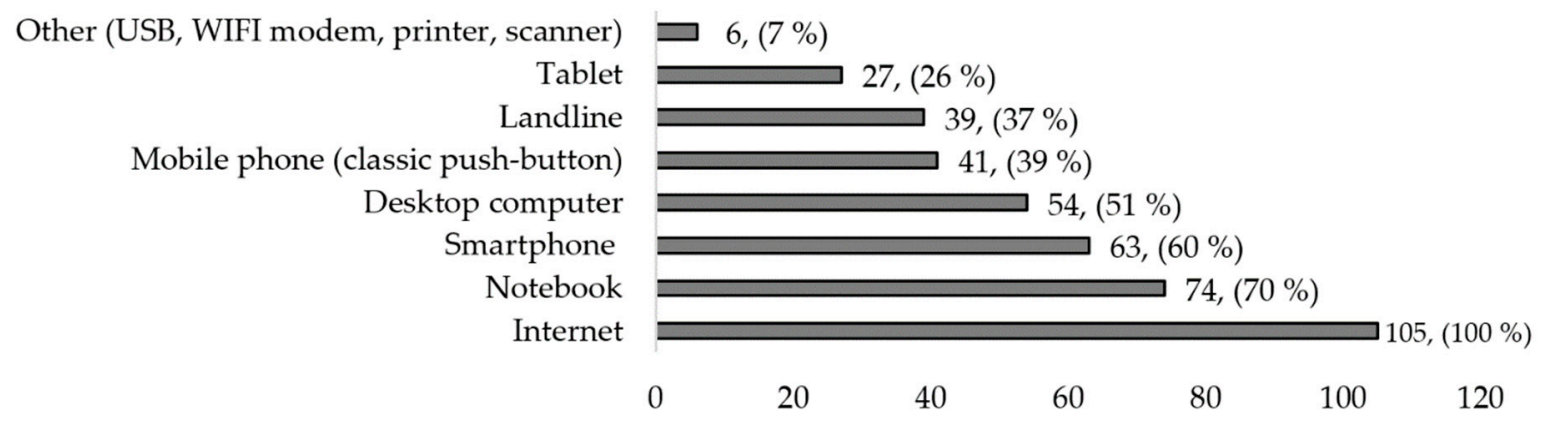

Figure 1. Social activation service for families with children (SAS) and shelter home for parents with children (SH) workers' access to individual devices (Information and communication technologies (ICTs) provided by the employer.

Among the options offered, all social workers stated that they had access to (1) the Internet. Most of them further stated that they had access provided by their employer to (2) a notebook, (3) a smartphone, and (4) a desktop computer. Only rarely did the respondents state that they had access to a tablet (this fact was stated by 27 respondents). If the respondents stated that they had access to other devices at work, they meant a USB and a WIFI modem to a computer for field work, a printer, or a scanner.

Subsequently, we asked the respondents how often they used individual programs in the performance of their job (see Appendix F). Almost all employees reported using e-mail (103), an Internet browser (95), and text programs (91) on a daily basis. Almost half of the respondents reported using spreadsheets (59), cloud services (59), and calendars and planners (46) on a daily basis. By contrast, nearly no one used presentation programs (90), teaching or educational programs (83), a data box (78), and an individual planning program (77) at all or less than once a month.

We also asked the respondents how important the individual programs were according to them in the performance of their job (see Appendix $G$ ). According to all respondents $(N=105)$, the most important ones are text programs (105) and e-mail (105). Most stated that the Internet browsers (102) and spreadsheet programs (99) were also important to them. The respondents most often cited presentation programs (46) as unimportant. We were surprised by the respondents stating that they did not use or know some programs, especially programs for individual planning. The majority of respondents (59) stated that they did not know or did not use such a program. Also, other programs, such as registration database systems, were considered unimportant by a large part of the respondents (53).

In the last part, we asked the workers of select social services for vulnerable children to give us their subjective evaluation of user skills in individual programs (see Table 1). 
Table 1. Subjective evaluation of user skills in individual programs by workers of social services for vulnerable children.

\begin{tabular}{|c|c|c|c|c|}
\hline Programs Supporting the Use of ICTs & Excellent * & Sufficient * & Insufficient * & Not Using/Not Knowing \\
\hline 1. E-mail & 103 & 2 & 0 & 0 \\
\hline $\begin{array}{l}\text { 2. Internet browser (Google, Seznam, } \\
\text { Centrum, Firefox, etc.) }\end{array}$ & 102 & 1 & 1 & 1 \\
\hline $\begin{array}{l}\text { 3. Text program (Microsoft Word, Libre } \\
\text { Office, etc.) }\end{array}$ & 94 & 10 & 1 & 0 \\
\hline $\begin{array}{l}\text { 4. Quick chat applications (Facebook } \\
\text { Messenger, WhatsApp, ICQ, } \\
\text { Skype, etc.) }\end{array}$ & 70 & 8 & 4 & 22 \\
\hline $\begin{array}{l}\text { 5. Calendars and planners } \\
\text { (Google calendar, etc.) }\end{array}$ & 63 & 11 & 6 & 25 \\
\hline $\begin{array}{l}\text { 6. Social networks (Facebook, Twitter, } \\
\text { Instagram, etc.) }\end{array}$ & 61 & 11 & 6 & 27 \\
\hline $\begin{array}{l}\text { 7. Cloud servicers (Google Disk, } \\
\text { Drop Box, etc.) }\end{array}$ & 60 & 16 & 6 & 23 \\
\hline $\begin{array}{l}\text { 8. Spreadsheet programs } \\
\text { (Microsoft Excel, etc.) }\end{array}$ & 59 & 37 & 9 & 0 \\
\hline $\begin{array}{l}\text { 9. Programs for creating presentations } \\
\text { (Microsoft Power Point, etc.) }\end{array}$ & 56 & 27 & 8 & 14 \\
\hline $\begin{array}{l}\text { 10. Record database systems } \\
\text { (ARUM, Highlander, etc.) }\end{array}$ & 41 & 4 & 2 & 58 \\
\hline 11. Program for individual planning & 28 & 6 & 1 & 70 \\
\hline 12. Teaching or educational programs & 24 & 22 & 7 & 52 \\
\hline 13. Data box & 23 & 12 & 10 & 60 \\
\hline
\end{tabular}

We found that the user skills of social workers in the field of ICTs were assessed sufficiently but only in certain areas. Social workers rated their user skills best in the use of e-mail (103), Internet browsers (102), text programs (94), and quick chat applications (70). However, in the case of other programs, they rated their user skills relatively highly, these being calendars and planners (63), social networks (61), cloud services (60), spreadsheet programs (59), and programs for creating presentations (56). According to social workers, their ICT skills (competences) were sufficient, even though 74 of them stated that they would like to continue their training in the field of ICT in social work. To the question "Indicate whether and in which areas of work with ITCs you would like to improve within your job", the respondents often stated that they would like to be trained in the field of spreadsheet programs (41). Social workers are open to learning about ICTs, as evidenced by a verbal comment on the question: "I want to know any technology that will make it easier for me to do social work." or "To know the options offered by the programs to make work easier". They also stated that they would like to be trained in an individual planning program (7): "I think that an individual planning program could be useful for my work." or "An intervention record program and an individual planning program: we record interventions using the Excel spreadsheets, and it is not optimal. Unfortunately, we do not have any program for individual planning." There were also suggestions for training in the field of Internet safety and training in user basics of working with ICTs, as evidenced by the following answer: "Working with a printer and a connection, or working with a text, reinstalling programs, and in general dealing with the basic problems when using a PC". Only 15 respondents stated that they did not need further training and 16 stated that they did not know whether they would like to continue their training in social work in ICTs and considered their user skills in social work sufficient.

We compared the evaluation of the subjective user skills of social workers with the only existing international survey of user skills of the adult population in the Czech Republic [34]. Out of the total number of respondents, $65 \%$ of Czech adults stated that they use a computer at work, and $89 \%$ use one at home or anywhere outside work. Most adults believe that their IT skills are sufficient for their profession (96\%) and that any insufficiencies in this type of skills do not affect their careers. This corresponds with our findings. This statement may be related to the fact that the use of computers 
at work is less widespread in the Czech Republic than in other countries where this international investigation took place. In terms of program use and activity structure, adults at home are more concerned with searching the Internet, using e-mail, and engaging more often in Internet discussions. In contrast, they use text and spreadsheet programs more at work and carry out financial and business transactions there more often. It is clear from this survey that the structure of activities that adults perform daily at home differs from activities that are performed at work. Another interesting finding is that the results of user skills of Czech adults in the field of ICT depend on age, education, and profession and the average is in a test of literacy and numeracy. However, the mentioned dependencies were not confirmed in our research among Czech SAS social workers; we critically reflect on this fact. A high level of reading and math skills then goes hand in hand with a high level of problem-solving skills in the digital environment. On the other hand, the low levels of reading and, especially, mathematical skills form a certain barrier in the effective use of ICT technologies and in working with information. Based on this finding, it can be stated that the policy makers and social service providers should reflect on the importance of ICT involvement in the process of further education of social workers. This can be applied as a legal obligation because, according to $\S 111$, "the employer is obliged to provide the social worker with further education in the range of at least 24 hours per calendar year." [16]. Social workers should be trained to understand the role of ICT in social work and to perceive ICT as an integral part of modern (digital) society. At the same time, as part of their interventions, they should mitigate the risks of e-exclusion of vulnerable children (with special emphasis on vulnerable children living in so-called socially excluded localities, which often become subject to at least triple exclusion: spatial segregation, and social and e-exclusion).

Using a one-dimensional analysis, we found that the most important for social workers are text and spreadsheet programs, e-mail, and an Internet browser to perform their job, which corresponds to the frequency of use and the evaluation of sufficient user skills in these areas. Limited user skills and lower frequency of use in the field of ICTs were found in the case of presentation programs (Microsoft Power Point), record database systems, individual planning programs, cloud services, teaching or educational programs, quick chat applications, and social networks. Earlier, Vávrová et al. [28] stated that even social workers may face low digital literacy. The digital literacy of social workers can vary, being especially dependent on age. Generational differences may arise between new young practitioners, most of whom have sufficient digital literacy and are able to use and adapt to alternative technologies for working with clients, and older social workers who are used to working on a typewriter instead of using a personal computer [35]. The first group can be described as "digital natives" [36], which are individuals born after 1980 [37], and the second are "digital immigrants" [36]. Digital natives can have an advantage over the second category as they grow with technologies practically from their childhood. Using a two-dimensional analysis, we examined whether age, education, and length of practice of social workers were related to user skills. According to Lupač [38], measuring ICT skills can be done in three ways: (1) by directly observing users while performing a task, (2) by asking about specific knowledge and skills of users, or (3) by users' self-assessing their skills. We chose the third way to measure ICT skills in our research. We formulated hypotheses with regard to the knowledge of practice, but we also drew on the results of research on digital skills [25,27].

We tested three hypotheses: (H1) The age of the worker is related to the level of his/her user skills in working with programs; (H2) qualification of the worker is related to the degree of his/her user skills in working with programs; and (H3) the length of the worker's experience is related to the degree of his/her user skills in working with programs. To test the hypotheses, we found out the correlation between the age, qualification, and length of practice of the workers and their user skills in working with programs: text programs, spreadsheet programs, programs for creating presentations, registration database system, program for individual planning, cloud services, calendars and planners, teaching or educational programs, email, data box, quick chat applications, social networks, Internet browsers, and Internet banking. In Appendix $\mathrm{H}$, we give an example of the hypotheses testing using Pearson's Chi-square. In all the hypotheses that serve as an example, we looked for a relationship between the 
age, qualification, and length of practice of the workers and their user skills in working with ITCs, specifically with MS Excel. According to the informants (presented in expert interviews), MS Excel requires a higher level of digital literacy, and also the need for further training in spreadsheet programs was expressed by social workers who participated in the questionnaire survey.

Due to the fact that none of the hypotheses were confirmed, we state that our research did not confirm a link between the subjectively assessed digital literacy of workers of selected social services for vulnerable children and their age, education, or length of practice. In our opinion, this may be influenced by the respondents' self-evaluation, when they do not have a realistic view on their digital skills or are not willing to share it.

\subsection{Qualitative Part of the Research}

We supplemented the quantitative survey with semi-structured interviews with representatives of the target group (parents and children from twenty families using SAS) and semi-structured interviews with experts (managers and senior members of select social activation services). As part of the project smart technologies for the improvement of quality of life in cities and regions, we launched an experimental verification in April 2020 (during the emergency period in the Czech Republic) aimed at preventing e-exclusion in the target group of disadvantaged families with children using SAS (in the city of Ostrava, i.e., the administrative center of the region with the largest so-called socially excluded localities and with the most cases of COVID-19; see Figure 2).

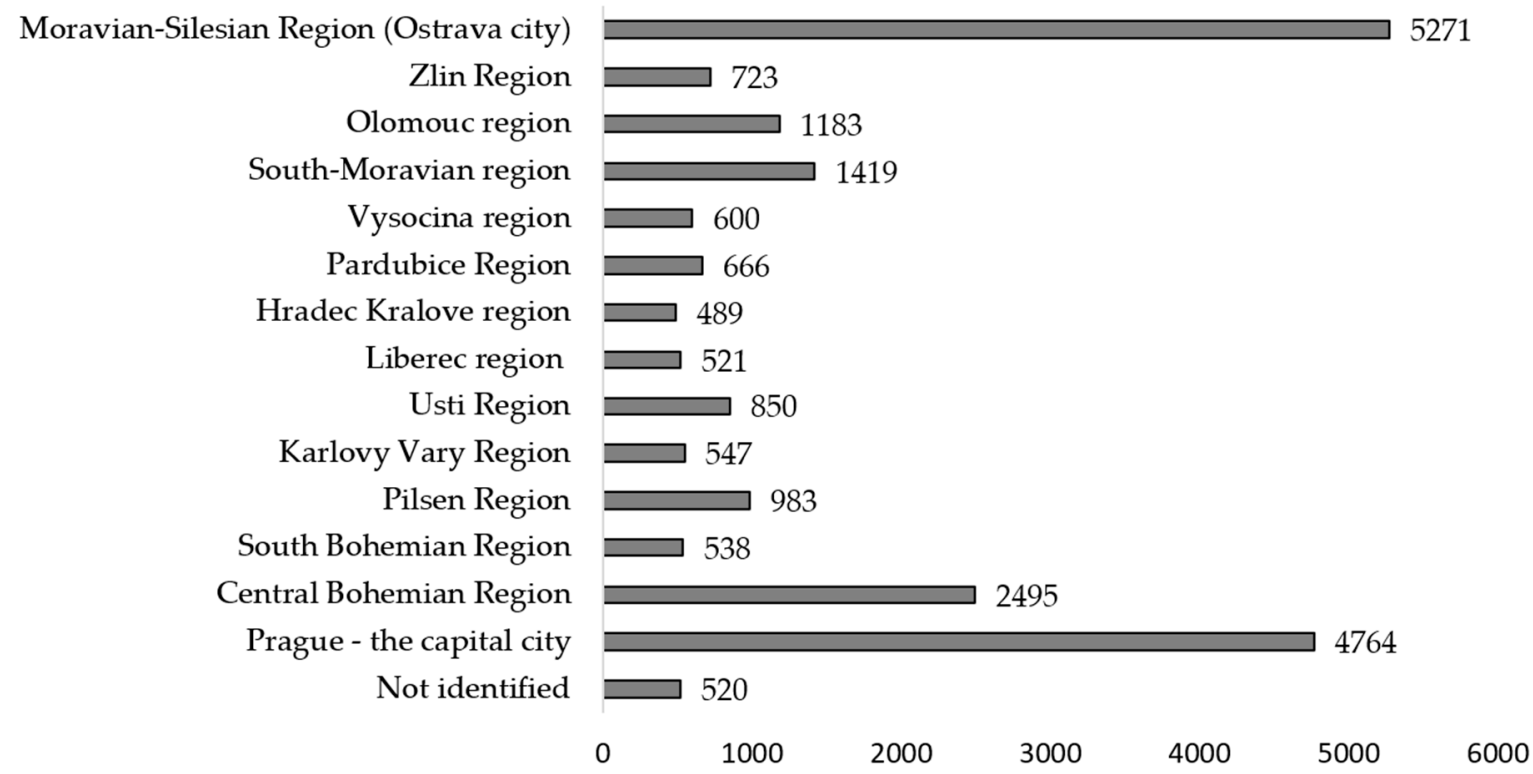

Figure 2. Total number of people with COVID-19: regions of the Czech Republic [39], 22 August 2020.

Through social services, we selected 20 families with children and gave them tablets with $20 \mathrm{~GB} /$ month of data for one year. These will be used for e-communication with SAS social workers who support these families in networking as well as in communication with the school and other important institutions and professionals (psychologists, psychiatrists, members of civic counseling, etc.), in e-mail communication, in searching for information on websites (schools, doctors, and interest groups) as well as in communication via web applications and social media, in accessing learning platforms (e.g., Padlet), and in viewing instructional and educational videos. While distributing the tablets to the families, we conducted interviews with the members of 20 families, the results of which we present below.

The interviews were conducted with parents, especially with mothers (19 out of 20) and minor children were also present at the interviews. The father was only present in one case. The interviewed clients used SAS services for 2 years on average and have 3 children on average (this is the median). 
In the families included in the research, the children were between 6 months and 16 years old. In the interviews, the representatives of the target group discussed their access to individual devices, the possibility of using the Internet, the importance of individual programs, and their subjective evaluation of their user skills in individual programs, including the identification of the need for further training in ICTs.

The statements of the communication partners show that most of the representatives of the target group (12 out of 20 ) have only access to a mobile phone or a smartphone. "I have a smartphone; this is it, isn't it? But, I don't have other ICTs, and now, we can't get anywhere to have a computer there." (5CP). The abbreviation CP (Communication Partner) after the statement indicates the number of the communication partners (mother/father). Most of them do not have access to other devices such as a desktop computer, a landline, a notebook, or a tablet (18 out of 20): "No, we don't have it at home, and now, you can't get anywhere as there is a lockdown and we're afraid, too. Like, at school, children have computers, but they are not always there either or as they would need, and again after school, they are not working computers either." (11CP).

An Internet connection is used by 14 out of 20 representatives of the target group, but only 12 of them have permanent Internet connections in their households. The communication partners who stated that they had access to the Internet were using it every day: "I am there every day; you always need to look for something, the tasks that the teacher sends to the children. Then, I look for a doctor's phone, for example, and without the Internet, I could not do it." (7CP). Another communication partner stated that she does not use the Internet, but her children do. Children need the Internet to be able to learn and to stay in touch with classmates or to use it as a source of entertainment, such as playing games, watching movies and videos, and listening to music. Parents most often use the Internet to search for information about health care, to find information from school for children when doing homework, or to search for information about transport connections in the city. They also use the Internet to communicate with their families and a wider social environment.

As for the importance of individual programs, the communication partners agreed that the most important thing for them is an Internet browser (Google, etc.) so that they could find necessary information for their daily life: "I search various things there: when the tram goes, then what [are] the pediatrician's office hours, or the teacher sends tasks to my boy there by e-mail. So, I watch it there, but the boy then has to rewrite it. He cannot fill in a form on his cell phone, so he rewrites it and then I tell the teacher when I will bring it to her." (8KP). They also mentioned the importance of quick chat applications (Facebook Messenger, etc.), "I have this application here in my mobile phone, and there, I communicate with my family or when I want to be in contact with someone. (2CP), and e-mail and social networks (Facebook, etc.). The communication partners rated their user skills best in the programs that are important to them (Internet browsers, quick chat applications, e-mail, and social networks). However, they rated their user skills as average (they rated their competencies only as sufficient): "Well, I don't know, I am not able to assess myself..., but maybe I would give myself grade three. I can do what I need." (4CP). Those communication partners who assessed their competencies as sufficient often mentioned the need for further training in ICTs.

The need for further training in ICTs was mentioned in the field of information retrieval (13), as evidenced by the following statements: "I would like to be able to write a $C V$, look for job offers." (1CP) or "to find information about housing, or about the doctors" (20CP), "to find things for children for school so that I can learn with them and find things for them to enjoy so that they can enjoy some fun when learning-one can find some entertaining educational tasks on the Internet, or they could watch educational videos." (4CP) and in other forms of communication (10) "Well, I need to arrange something at the office or with the school, and I would like to know that. Maybe even sending emails would help me, but I don't have an email." (5CP).

Four expert interviews with senior SAS social workers confirmed that the COVID-19 pandemic emergency was a difficult time for their services. It was a situation they had never experienced before, so they could not be prepared for it in advance. In addition, the state erroneously suspended, by Government Resolution No. 239 of 16 March 2020, the provision of the SAS social service together 
with other, for example, low-threshold services for children and youth. "In practice, this has led to a controlled but uncompensated disconnection of vulnerable families with children from excluded localities from any assistance" (SW3). The abbreviation SW (Social Worker) after the statement indicates the number of the communication partner (social worker-service manager). However, social workers provided the SAS service despite the ban, mainly in a contactless form, aware of the possible sanctions. "Our social workers regularly called clients because they usually do not have pay-as-you-go mobile phones." (SW2). "Families were contacted by the service staff by telephone and in the case of families without the possibility of distance communication by a personal visit while keeping security measures. Some families were well acquainted with the emergency conditions and understood the limitations; some families learned about the measures only from service workers; some did not understand what was allowed and what was forbidden." (SW3). Another major challenge, not only for social workers, was online schooling during the period of the emergency measures. "A separate issue was the preparation of children for school as the vast majority of the families did not have the equipment for online teaching or could not use it." (SW3). "Many client families were not/are not ready to use at least partly digital technologies, the reasons being not only material (they do not have equipment or the connection), but also in the area of skills, some of them being on the edge of their abilities and needing more to be educated in terms of the basic social skills that life in today's society requires." (SW3). "It is not common for clients to have an Internet connection, either" (SW1). "The online schooling was a great challenge because our clients do not have the necessary ICT competencies." (SW2). In conclusion, we may state that the pandemic and the associated emergency measures tested the readiness of the social system to support vulnerable families with children, when it detected the so-called white spots. "If other waves of COVID-19 pandemic come, our families will need increased support in the area of ICTs." (SW1). "We understand that the situation of the families we are visiting was even more difficult during the pandemic than that of ordinary families. They were even more isolated and cutoff from common social contacts due to the absence of communication in the online environment, mainly due to their low digital competencies." (SW4). This situation highlighted the need to take concrete steps to prevent e-exclusion, especially in the case of endangered groups to which "vulnerable" families with children certainly belong.

\subsection{Summary of Research Results}

In this section, we present a summary of the research results and answers to the main research question: What is the situation like in the use of ICTs in Czech social work with vulnerable children? The main question includes partial research questions: (1) How do social workers working with the given target group perceive their digital skills? (2) How do SAS users in one de-industrialized city (Ostrava) evaluate their digital skills in relation to the situation during the emergency? (3) How do experts from SAS assess the use of ICTs in the emergency related to the COVID-19 pandemic?

When dealing with partial research question (1), we drew on questionnaire survey. Based on an online questionnaire survey $(\mathrm{N}=105)$, we found that the most important for social workers is text and spreadsheet programs, e-mail, and an Internet browser for the performance of their job, which corresponds to the frequency of their use and evaluation of sufficient user skills in these areas. Limited user skills and lower frequency of using ICTs were found out in presentation programs (Microsoft Power Point), record database systems, individual planning programs, cloud services, teaching or educational programs, quick chat applications, and social networks. Based on the tested hypotheses, we can state that there is no connection between the subjectively assessed digital literacy of workers of selected social services for vulnerable children and their age, education, or length of practice. In our opinion, this fact may be influenced by the self-evaluation, when respondents do not have a realistic view of their digital skills or are not willing to share it.

When dealing with partial research question (2), we consider it an important finding that 14 out of 20 representatives of the target group (families in which experimental verification was carried out) used an Internet connection but that only 12 of them had permanent Internet connections in their households. According to Hargittai's research [40], differences in young people's skills are linked to the extent of their access to the Internet. Lower ICT skills can be found in individuals who have limited access to 
the Internet and, furthermore, in a regulated environment (schools and public libraries). According to the author, digital inequality is related to the quality of access to the Internet, which correlates with socioeconomic status. Being connected to the Internet without restriction is described by Hargittai as "autonomy of use". Autonomy of use has an impact on how intense a user's involvement in the online world is and how it benefits him/her. Young people who only rely on public options of the Internet connection, such as schools and libraries, often face significant obstacles (opening hours, long distance to the library, quality of equipment, etc.). In her research, Bodyová [41] compared the ICT skills of young people who had unrestricted access to the Internet and young people who had a limited one. She found that the skills of using ICTs to meet one's own needs are worse in the case of young people with limited access when compared to young people with unrestricted access. Based on field research, she states that different approaches to ICTs lead to different types of activities in the virtual space and different levels of participation. She found that when young people were using Facebook as a source of entertainment and social contacts, the differences in ICT skills were negligible. Significant differences only became apparent when young people used ICTs as a tool to obtain information and support. The need for systematic education in the field of ICT competences has also been pointed out in the conclusions of a research report from England. Age, gender, race, and socioeconomic status are factors that contribute to whether young people have an opportunity to develop the skills necessary for digital literacy. Children and young people from higher-income households are much more likely to have access to the state-of-the-art technology. This means that they have an opportunity to figure out how to use these technologies, either by trial and error or by guidance from parents. It is also much more likely that these children will be taught to search for information, to evaluate it, and to sort it. In this respect, the role of educators is irreplaceable [42].

In terms of the importance of individual programs, the communication partners (representatives of SAS client families) agreed in our research that the most important thing for them was an Internet browser (Google, etc.) because they could find the necessary information. They also mentioned applications for quick chatting (Facebook Messenger, etc.), e-mail, and social networks (Facebook, etc.) to be important. The communication partners rated their user skills best in the programs that were important to them (Internet browser, quick chat applications, e-mail, and social networks). However, they generally rated their user skills as average (they only rated their competencies to be sufficient). Those communication partners who assessed their competencies as sufficient often mentioned the need for further education in ICT.

When dealing with partial research question (3), we examined the views of experts from SAS on the situation connected with the pandemic COVID-19. Furthermore, based on the results of interviews with experts from SAS $(\mathrm{N}=4)$, we found that representatives of the target group (vulnerable children and their families) mostly had access only to mobile phones or smartphones. However, this fact appeared to be locally and temporally conditioned in the research, as expert interviews (two were conducted in August 2020) showed that many foundations and other institutions later provided SAS clients with tablets, computers, and other devices to support the online teaching of children, which is only one factor of the necessary support. The second one is internet connection and digital skills. The problem of internet connection is related to the fact that the SAS service is provided mostly to children from so-called low-income families, often living in nonstandard forms of housing. The lower digital competence of parents is then related to the lower level of their education. It follows from the above that parents are not mostly a support for their children in the development of digital literacy. Support in this area is often provided by social workers instead.

\section{Discussion and Conclusions}

The aim of social work based on the socio-ecological approach is to maintain a balance between people and the environment: to support their development, growth, and adaptive capacity; to remove barriers in the environment; and to improve the ability of the environment to respond adequately to people's needs. Based on the needs analysis which we carried out as part of the pre-empirical phase of 
the presented research, we found that disadvantaged families with children faced mainly problems in getting various types of information (e.g., from school electronic student books or from physicians giving patients information, using e-governments or communication with various institutions). There is a new challenge for social workers to deal with these problems and to help the service users cope with them. Otherwise, there may be a further deepening of e-exclusion, various forms of which are often faced by disadvantaged families with children. The disadvantage was also manifested in connection with the declaration of the emergency and the Covid-19 pandemic when teaching of children and communication with the school was completely moved to the online regime. Direct social work with families within the social and legal protection of children was also limited, and social work interventions for users of social activation services were often carried out in alternative ways using ICT technologies. These alternative approaches were "hampered" in some cases by the unavailability of ICTs in families of children at risk.

The aim of the study was (1) to draw attention to the e-exclusion of vulnerable children as a systemic (socio-ecological) problem that is gaining momentum during emergencies; (2) to reflect the subjectively perceived readiness of social workers as one group of the actors in the system, whose task is to contribute to the mitigation of risks arising from the e-exclusion of the target group and to ensure the sustainable development of society; (3) from the position of the target group, to reflect the situation of their digital literacy and thus exclusion; and (4) to make recommendations to public policy makers and social workers to mitigate these risks and to promote sustainability.

With regard to (1), as already described by Vávrová et al. [28], many social workers fear the risk of deepening e-exclusion in the target group of vulnerable children and families. Their concerns stem from the socio-technological development and the limited digital skills and economic resources of their clients. This fact clearly manifested itself in Czech society at the time of emergency related to the COVID-19 pandemic, when teaching and field social services for the given target group were transferred to the online environment. Based on previous findings and our research, we have come to the conclusion that it is necessary to prevent the accumulation of risk factors such as limited access to ICT, limited ICT user skills, low socioeconomic status of families, and socio-spatial segregation of the population, which is typical of de-industrialized cities, such as Ostrava. The accumulation of risk factors often leads to e-exclusion and its further problems in vulnerable children. According to the socio-ecological approach $[19,21]$, the goal in social work is to support clients in their adaptability to changing conditions-namely, transition of society to a digital (online) society so as to support their resilience [43] and to support the prevention of their e-exclusion [44-46]. Social work should improve and create conditions for ICT learning and adaptation of the target group (vulnerable children) to the changing micro, meso, and macro environments.

With regard to (2), given the findings that subjectively assessed user skills of social workers in the field of ICT are assessed as sufficient (but only in certain areas), we believe that the founders of social services should begin to seriously consider the mandatory inclusion of programs supporting the development of digital skills in further education. Social workers should be trained to understand the role of ICT in social work and to be able to use its potential in their interventions. In relation to policy makers, it is important to consider including the requirement of new competencies for the exercise of the social work profession in general and in connection with individual types of social services and to then expand their legally established basic activities. Specifically, pursuant to Section 65 of Act No. 108/2006 Coll., on Social Services, SAS provides the following activities: (a) education, training, and activation; (b) mediation of contact with the social environment; (c) social therapeutic activities; and (d) assistance in exercising rights and legitimate interests and in dealing with personal matters. It is therefore worth considering whether the given list should not be supplemented in order to apply to the online environment, too, or to emphasize this fact in the methodological instructions issued by the Ministry of Labor and Social Affairs of the Czech Republic. At present, the Czech Republic does not offer further education courses for social workers focused on methods of working with clients in the field of digital skills within legally established activities or the necessary methodology. In addition 
to the need for further education in the field of ICT, many authors point to the need for educating social workers in other areas [47-51]. These could be closely linked to the concept of sustainability, which would help them better manage the solution of social situations in relation not only to clients but also to themselves because social workers work in (a) precarious, (b) complex, and (c) managerially oriented work environment $[49,52,53]$, which puts pressure on their competencies, including the digital ones.

With regard to (3), regarding the findings concerning the target group (vulnerable families with children), they rated their user skills as average to below average. However, they were aware of the need for further education in this area. They expected higher digital literacy to help them improve their quality of life. As for social work with the given target group while using ICTs, policy makers can find inspiration abroad [54-56]. In social work with children and youth, there is a trend to use ICTs, as indicated by Chan's study [57], which provides a systematic overview of social work interventions with young people using ICTs. The author gave examples of research that showed that ICTs in specific aspects increased the effectiveness of social work with young people but also pointed out issues related to the limits of different types of ICTs and the professional competence of social workers in the use of ICTs. Australia, among others, is an example of good practice in relation to setting up work with ICTs in social services. This country has been using ICTs in social work for a long time and reflects on this topic in professional discussions [58]. Social workers use ICTs in various forms in their work, many of them being rare in the Czech Republic. Australia holds the world's number one position in the development of ICT issues in practice. Australian non-profit organizations (corresponding to social activation services for families with children in the Czech Republic) also commonly use ICTs when working with disadvantaged families and their children. For Czech social work, the implementation of methods using ICTs into practice and into the system of education of future social workers thus becomes a challenge for the 21st century which can be inspired by good practice from abroad.

With regard to (4), the recommendations for public policy makers and social workers to support e-inclusion of the target group are based not only on our research but also on a sample survey on information and communication technologies in households and their use by individuals [59]. According to this survey, ICTs contribute to digital literacy of the population and are an important indicator of how willing people are to participate in the digital society and whether they have sufficient financial resources to do so. In 2019, 78\% of Czech households had access to ICT (computer and tablet) and $81 \%$ of them had access to the Internet. Computers and the Internet have become a common part of households in the Czech Republic over the last ten years-for comparison, in 2009 only $54 \%$ of households had a computer and $49 \%$ had an Internet connection. The policy makers should reflect on the fact that Internet access is strongly correlated with household income. In one-fifth of the poorest households, only half of such households have access to the Internet, which is an alarming finding. In contrast, in one-fifth of the highest-income households, almost all households have access to the Internet (99\%). These findings support Keller's argument [60] that, in post-industrial society, there has been a sharp increase in financial and other inequalities in the social area. Unequal social arrangements are also affected by the layout of cities, which leads to an increase in socio-spatial segregation of the population (e.g., the wealthy people live in residential areas, and the poor are pushed into urban areas), this is characteristic of de-industrialized cities, too, such as Ostrava. In this context, sustainability plays a key role as a means of reducing social and other inequalities. Sustainability is understood as a new paradigm of social work which has a social, economic, and physical dimensions and in which social workers can play a key role, especially in improving the individual dimensions of sustainability and human well-being [22]. The main recommendation to public policy makers thus aims at the allocation of financial resources needed for the preparation and subsequent implementation of solutions at the level of social work interventions embedded in the socio-ecological paradigm. This should specifically lead to the creation and subsequent implementation of a national methodology for preventing e-exclusion of vulnerable children. We expect that this approach could help eliminate the "digital" disadvantage of already disadvantaged children [61-63]. 
Finally, we present the limits and specifics of the submitted research and suggestions for further research. First of all, it is necessary to mention the limits of the quantitative part of the research, which involved a lower number of social workers than would be desirable. This fact is due to the "supersaturation" of social workers by various types of research carried out, for example, within the framework of university diploma theses. The level of willingness to participate in further research is generally low among Czech social workers. The fact that our hypothesis about the influence of age on the subjectively assessed level of digital skills of SAS social workers is not confirmed is an interesting finding that may signal another of the limits of the online research. It is likely that social workers with a higher level of digital competences (regardless of age) will be more involved in the online survey. This fact is then, in addition to the low number of respondents and the high degree of subjectivity of the answers, another of the reflected limits. Due to this, the quantitative survey was only a part of the presented research. In the implementation of the qualitative part of our research related to experimental verification, we used the synergistic effects of the interdisciplinary project smart technologies for the improvement of quality of life in cities and regions and the involvement of partner organizations from practice. Within them, for example, we carried out the training of social workers from cooperating organizations in the use of ICT. These facts helped us in networking informants from the ranks of social service users through key workers. Interdisciplinary cooperation in preventing e-exclusion appears to be effective and desirable, which can be an important stimulus for educators in social work and for public policy makers. Based on the cost-benefit analysis, it turns out that, for evaluation of the financial impacts of the implementation of experimental verification (focused on the use of ICT in SAS), it would be desirable to further monitor the school achievements of the involved children or their social resilience, the family living trajectory, and their parents' employment. According to Hämäläinen, Pihlainen, and Vornanen, the changing social structures and social situations of families with children in working life, education, and digitalization are not discussed in terms of social sustainability [64], which opens up further space for social scientists dealing with digitalization of social work. For SAS, it would be desirable to model a simulation of the costs of using ICT in social work interventions (with an emphasis on the time aspect) and to compare this with the baseline. Following the project, our next step will be to develop a methodology aimed at preventing e-exclusion of vulnerable children in social work interventions (in SAS).

Author Contributions: Conceptualization, S.K. and I.K.; methodology, S.K. and I.K.; formal analysis, S.K. and I.K.; investigation, S.K. and I.K.; resources, S.K. and I.K.; data curation, S.K. and I.K.; writing-original draft preparation, S.K. and I.K.; writing-review and editing, S.K. and I.K.; project administration, S.K. and I.K. All authors have read and agreed to the published version of the manuscript.

Funding: This research paper was written as a part of a research project of a long-term intersectoral collaboration "Smart technologies for the improvement of quality of life in cities and regions", identification number CZ.02.1.01/0.0/0.0/17_049/0008452. This project is funded by European Union Social Fund, Operational Programme "Research, Development, and Education" managed by the Ministry of Education, Youth, and Sports of the Czech Republic. The manager of the project consortium is the Faculty of Science, University of Ostrava.

Acknowledgments: We would like to express our thanks to colleagues from the research team Faculty of Social Studies, University of Ostrava in project "Smart technologies for the improvement of quality of life in cities and regions". We would like to express our thanks to the reviewers.

Conflicts of Interest: The authors declare no conflict of interest. The funders had no role in the design of the study; in the collection, analyses, or interpretation of data; in the writing of the manuscript; or in the decision to publish the results.

\section{Appendix A. Questionnaire-A Variant: For Social Workers of Shelters and Social Activation Services for Families with Children}

Dear colleagues,

We are members of the research team of the Faculty of Social Studies of the University of Ostrava. We want to find out how social workers/workers in social services of shelters and social activation services for families with children use ICT in their work. Please take a few minutes to complete the 
following questionnaire. The questionnaire has 11 questions and is completely anonymous. It will take you about 10-15 minutes to complete.

The results will help us suggest procedures for the use of ICT in social work.

1.What is your gender?

(a) woman

(b) male

2. What is your age (in years)?

An open question

3. What is your qualification according to Section 110, Act No. 108/2006 Coll?

(a) Accredited course of a worker in social services

(b) Higher vocational education

(c) Higher education

4. What social service do you work in?

(a) shelter (according to Section 57, Act No. 108/2006 Coll.)

(b) social activation service for families with children (according to Section 65, Act No. 108/2006 Coll.)

5. What is the length of your internship (in years) in social work (during your entire career)? Open answer

6. What is the length of your working (in years) in the social service and where you work now? Open answer

7. What facilities (provided by the employer) do you have access to in your work? (you can choose more than one answer)

(a) mobile phone (push-button)

(b) smartphone

(c) landline telephone

(d) desktop computer

(e) notebook

(f) tablet

(g) Internet

(h) other (specify)

8. Determine on the scale how often you use each program to perform your job

Choose one answer for each line

Table A1. Frequency of program use.

\begin{tabular}{ll}
\hline Text programs (Microsoft Word, Libre Office, etc.) & $\begin{array}{l}\text { daily-at least once a week-at least once a } \\
\text { month-less than once a month-not at all }\end{array}$ \\
\hline Spreadsheet programs (Microsoft Excel, etc.) & $\begin{array}{l}\text { daily-at least once a week-at least once a } \\
\text { month-less than once a month-not at all }\end{array}$ \\
\hline Presentation programs (Microsoft Power Point, etc.) & $\begin{array}{l}\text { daily-at least once a week-at least once a } \\
\text { month-less than once a month-not at all }\end{array}$ \\
\hline Database systems (Highlander, ARUM, etc.) & $\begin{array}{l}\text { daily-at least once a week-at least once a } \\
\text { month-less than once a month-not at all }\end{array}$ \\
\hline
\end{tabular}


Table A1. Cont.

\begin{tabular}{ll}
\hline Program for individual planning & $\begin{array}{l}\text { daily-at least once a week-at least once a } \\
\text { month-less than once a month-not at all }\end{array}$ \\
\hline Cloud services (Google Disk, Drop Box, etc.) & $\begin{array}{l}\text { daily-at least once a week-at least once a } \\
\text { month-less than once a month-not at all }\end{array}$ \\
\hline Calendars or schedulers (Google Calendar, etc.) & $\begin{array}{l}\text { daily-at least once a week-at least once a } \\
\text { month-less than once a month-not at all }\end{array}$ \\
\hline Teaching or training programs (for the purposes of the job) & $\begin{array}{l}\text { daily-at least once a week-at least once a } \\
\text { month-less than once a month-not at all }\end{array}$ \\
\hline E-mail & $\begin{array}{l}\text { daily-at least once a week-at least once a } \\
\text { month-less than once a month-not at all }\end{array}$ \\
\hline Data box & $\begin{array}{l}\text { daily-at least once a week-at least once a } \\
\text { month-less than once a month-not at all }\end{array}$ \\
\hline $\begin{array}{l}\text { Quick chat applications (Facebook Messenger, WhatsApp, } \\
\text { ICQ, Skype, Viber, Snapchat, etc.) }\end{array}$ & $\begin{array}{l}\text { daily-at least once a week-at least once a } \\
\text { month-less than once a month-not at all }\end{array}$ \\
\hline Social networks (Facebook, Twitter, Instagram, etc.) & $\begin{array}{l}\text { daily-at least once a week-at least once a } \\
\text { month-less than once a month-not at all }\end{array}$ \\
\hline $\begin{array}{l}\text { Internet search engines (Google, Seznam, Centrum, } \\
\text { Firefox, etc.) }\end{array}$ & $\begin{array}{l}\text { daily-at least once a week-at least once a } \\
\text { month-less than once a month-not at all }\end{array}$ \\
\hline
\end{tabular}

9. Determine on the scale how important individual programs are for you in performing your job. Choose one answer for each line.

Table A2. Importance of programs.

\begin{tabular}{|c|c|}
\hline $\begin{array}{l}\text { Text programs (Microsoft Word, } \\
\text { Libre Office, etc.) }\end{array}$ & $\begin{array}{l}\text { important - rather important-rather } \\
\text { unimportant-unimportant-I do not use/do not know }\end{array}$ \\
\hline $\begin{array}{l}\text { Spreadsheet programs } \\
\text { (Microsoft Excel, etc.) }\end{array}$ & $\begin{array}{l}\text { important-rather important-rather } \\
\text { unimportant-unimportant-I do not use/do not know }\end{array}$ \\
\hline $\begin{array}{l}\text { Presentation programs } \\
\text { (Microsoft Power Point, etc.) }\end{array}$ & $\begin{array}{l}\text { important-rather important-rather } \\
\text { unimportant-unimportant-I do not use/do not know }\end{array}$ \\
\hline $\begin{array}{l}\text { Database systems (Highlander, } \\
\text { ARUM, etc.) }\end{array}$ & $\begin{array}{l}\text { important-rather important-rather } \\
\text { unimportant-unimportant-I do not use/do not know }\end{array}$ \\
\hline Program for individual planning & $\begin{array}{l}\text { important-rather important-rather unimportant - } \\
\text { unimportant - I do not use/do not know }\end{array}$ \\
\hline $\begin{array}{l}\text { Cloud services (Google Disk, Drop } \\
\text { Box, etc.) }\end{array}$ & $\begin{array}{l}\text { important-rather important-rather } \\
\text { unimportant-unimportant - I do not use/do not know }\end{array}$ \\
\hline $\begin{array}{l}\text { Calendars or schedulers } \\
\text { (Google Calendar, etc.) }\end{array}$ & $\begin{array}{l}\text { important-rather important-rather } \\
\text { unimportant-unimportant - I do not use/do not know }\end{array}$ \\
\hline $\begin{array}{l}\text { Teaching or training programs (for the } \\
\text { purposes of the job) }\end{array}$ & $\begin{array}{l}\text { important-rather important-rather } \\
\text { unimportant-unimportant-I do not use/do not know }\end{array}$ \\
\hline E-mail & $\begin{array}{l}\text { important-rather important-rather } \\
\text { unimportant-unimportant - I do not use/do not know }\end{array}$ \\
\hline Data box & $\begin{array}{l}\text { important-rather important-rather unimportant - } \\
\text { unimportant - I do not use/do not know }\end{array}$ \\
\hline $\begin{array}{l}\text { Quick chat applications } \\
\text { (Facebook Messenger, WhatsApp, ICQ, } \\
\text { Skype, Viber, Snapchat, etc.) }\end{array}$ & $\begin{array}{l}\text { important-rather important-rather } \\
\text { unimportant-unimportant-I do not use/do not know }\end{array}$ \\
\hline $\begin{array}{l}\text { Social networks (Facebook, Twitter, } \\
\text { Instagram, etc.) }\end{array}$ & $\begin{array}{l}\text { important - rather important-rather } \\
\text { unimportant-unimportant - I do not use/do not know }\end{array}$ \\
\hline $\begin{array}{l}\text { Internet search engines (Google, Seznam, } \\
\text { Centrum, Firefox, etc.) }\end{array}$ & $\begin{array}{l}\text { important-rather important-rather } \\
\text { unimportant-unimportant-I do not use/do not know }\end{array}$ \\
\hline Other (specify): & $\begin{array}{l}\text { important-rather important-rather } \\
\text { unimportant-unimportant - I do not use/do not know }\end{array}$ \\
\hline
\end{tabular}


10. Determine on the scale how you rate your user skills for each program.

Mark yourself as if you are at school on a scale of 1-5 (1-best, 5-worst).

Table A3. Digital skills assessment.

\begin{tabular}{|c|c|}
\hline Text programs (Microsoft Word, Libre Office, etc.) & 1-2-3-4-5-I do not know/I do not use \\
\hline Spreadsheet programs (Microsoft Excel, etc.) & 1-2-3-4-5-I do not know/I do not use \\
\hline Presentation programs (Microsoft Power Point, etc.) & 1-2-3-4-5-I do not know/I do not use \\
\hline Database systems (Highlander, ARUM, etc.) & 1-2-3-4-5-I do not know/I do not use \\
\hline Program for individual planning & 1-2-3-4-5-I do not know/I do not use \\
\hline Cloud services (Google Disk, Drop Box, etc.) & 1-2-3-4-5-I do not know/I do not use \\
\hline Calendars or schedulers (Google Calendar, etc.) & 1-2-3-4-5-I do not know/I do not use \\
\hline Teaching or training programs (for the purposes of the job) & 1-2-3-4-5-I do not know/I do not use \\
\hline E-mail & 1-2-3-4-5-I do not know/I do not use \\
\hline Data box & 1-2-3-4-5-I do not know/I do not use \\
\hline $\begin{array}{l}\text { Quick chat applications (Facebook Messenger, WhatsApp, ICQ, } \\
\text { Skype, Viber, Snapchat, etc.) }\end{array}$ & 1-2-3-4-5-I do not know/I do not use \\
\hline Social networks (Facebook, Twitter, Instagram, etc.) & 1-2-3-4-5-I do not know/I do not use \\
\hline Internet search engines (Google, Seznam, Centrum, Firefox, etc.) & 1-2-3-4-5-I do not know/I do not use \\
\hline Other (specify): & 1-2-3-4-5-I do not know/I do not use \\
\hline
\end{tabular}

11. Indicate in what technologies you would like to improve yourself within social work.

Please describe these areas in as much detail as possible.

\section{Appendix B. The semi-Structured Interview Scenario for SAS Clients}

The 1st phase of research (before the experimental verification, i.e., when distributing tablets to families):

1. What is your experience with using ICT?

2. Can you please describe how you use ICT (how often and for what)?

3. Can you please describe how your children use ICT (how often and for what)?

4. How do you assess your skills in using ICT (what can you do, and is there anything you would like to be able to do and you are not)?

5. How do you assess your children's skills in using ICT?

6. As part of the experimental verification, you will now have a tablet with a data plan at your disposal. Please describe how you expect to use it?

7. ould you like to add/mention anything else in connection with the use of ICT?

\section{Appendix C. The Scenario for Expert Interviews}

1. Please tell me how your service (SAS) worked during the emergency measures related to the COVID-19 pandemic?

2. Please describe how the families of vulnerable children using your services adapted to the online environment during the emergency measures related to the COVID-19 pandemic (what was their situation)?

3. Describe how the online teaching (school preparation) of vulnerable children took place during the emergency measures related to the COVID-19 pandemic? 


\section{Appendix D. Informed Consent}

Informed consent to participate in the interview for the needs of the research smart technology for improving the quality of life of the inhabitants of cities and regions CZ.02.1.01/0.0/0.0/17_049/0008452

Dear madam and dear sir,

The interview, which we will conduct together, will serve not only for the needs of elaborating a research report on the project smart technologies for improving the quality of life of the inhabitants of cities and regions CZ.02.1.01/0.0/0.0/17_049/0008452.

As part of the research, interviews will be conducted, which will be recorded on a dictaphone, transcribed into text, and anonymized, and the recordings will subsequently be deleted. Only members of the research team will have access to the transcribed interviews. Your name (s) (or names of your children) * and names of persons or organizations you will mention during the interview will not be mentioned anywhere. Within the research, a partial and final research report will be made, and several expert articles will be written.

Your participation in the research is voluntary, and you can withdraw at any time during the interview.

By signing, I agree to my participation in the research.

Date:

Signature of the research participant:

* delete where not applicable

Appendix E. The Characteristics of the Respondents According to Selected Sociodemographic Indicators

Table A4. Characteristics of the respondents.

\begin{tabular}{|c|c|c|}
\hline Sociodemographic Indicators & Absolute Frequency & Relative Frequency \\
\hline \multicolumn{3}{|l|}{ Sex } \\
\hline Male & 5 & $5 \%$ \\
\hline Female & 100 & $95 \%$ \\
\hline \multicolumn{3}{|l|}{ Age } \\
\hline $18-30$ & 39 & $37 \%$ \\
\hline $31-45$ & 51 & $49 \%$ \\
\hline $46-60$ & 15 & $14 \%$ \\
\hline \multicolumn{3}{|l|}{ Qualification } \\
\hline $\begin{array}{l}\text { Accredited course for a worker in } \\
\text { social services }\end{array}$ & 10 & $10 \%$ \\
\hline Higher vocational education & 22 & $20 \%$ \\
\hline Higher education & 73 & $70 \%$ \\
\hline \multicolumn{3}{|l|}{ Type of social service } \\
\hline SAS & 89 & $85 \%$ \\
\hline $\mathrm{SH}$ & 16 & $15 \%$ \\
\hline \multicolumn{3}{|c|}{ Length of practice for the entire career } \\
\hline $0-5$ & 49 & $47 \%$ \\
\hline $6-10$ & 29 & $27 \%$ \\
\hline 11 and more years & 27 & $26 \%$ \\
\hline \multicolumn{3}{|c|}{ Current length of practice in social service, either SAS or SH } \\
\hline $0-5$ & 78 & $74 \%$ \\
\hline $6-10$ & 17 & $16 \%$ \\
\hline 11 and more years & 10 & $10 \%$ \\
\hline
\end{tabular}




\section{Appendix F. The Respondents' Use of Individual Programs}

Table A5. The respondents' use of individual programs.

\begin{tabular}{lccc}
\hline Programs Supporting the Use of ICT & Daily & At Least Once a Month & $\begin{array}{c}\text { Less than Once a Month } \\
\text { or Not at All }\end{array}$ \\
\hline 1. E-mail & 103 & 2 & 0 \\
\hline $\begin{array}{l}\text { 2. Internet browser (Google, Seznam, } \\
\text { Centrum, Firefox, etc.) }\end{array}$ & 95 & 10 & 0 \\
\hline $\begin{array}{l}\text { 3. Text programs (Microsoft Word, } \\
\text { Libre Office, etc.) }\end{array}$ & 91 & 14 & 0 \\
\hline $\begin{array}{l}\text { 4. Spreadsheet programs } \\
\text { (Microsoft Excel, etc.) }\end{array}$ & 59 & 44 & 2 \\
\hline $\begin{array}{l}\text { 5. Cloud services (Google Disk, } \\
\text { Drop Box, etc.) }\end{array}$ & 59 & 14 & 32 \\
\hline $\begin{array}{l}\text { 6. Calendars and planners } \\
\text { (Google Calendar, etc.) }\end{array}$ & 46 & 18 & 61 \\
\hline $\begin{array}{l}\text { 7. Registration database system } \\
\text { (ARUM, Highlander, etc.) }\end{array}$ & 34 & 5 & 56 \\
\hline $\begin{array}{l}\text { 8. Quick chat applications } \\
\text { (Facebook Messenger, WhatsApp, ICQ, } \\
\text { Skype, etc.) }\end{array}$ & 29 & 23 & 55 \\
\hline $\begin{array}{l}\text { 9. Social networks (Facebook, Twitter, } \\
\text { Instagram, etc.) }\end{array}$ & 22 & 28 & 77 \\
\hline $\begin{array}{l}\text { 10. Program for individual planning } \\
\text { 11. Data box }\end{array}$ & 14 & 14 & 78 \\
\hline $\begin{array}{l}\text { 12. Teaching or educational programs } \\
\text { 13. Programs for creating presentations } \\
\text { (Microsoft Power Point, etc.) }\end{array}$ & 4 & 23 & 83 \\
\hline
\end{tabular}

\section{Appendix G. The Degree of Importance Given by the Workers to Individual Programs}

Table A6. The degree of importance given by the workers to individual programs.

\begin{tabular}{lccc}
\hline Programs Supporting the Use of ICTs & Important & Unimportant & Not Using/Not Knowing \\
\hline 1. E-mail & 105 & 0 & 0 \\
\hline $\begin{array}{l}\text { 2. Text programs (Microsoft Word, } \\
\text { Libre Office, etc.) }\end{array}$ & 105 & 0 & 0 \\
\hline $\begin{array}{l}\text { 3. Internet browser (Google, Seznam, } \\
\text { Centrum, Firefox, etc.) }\end{array}$ & 102 & 2 & 1 \\
\hline $\begin{array}{l}\text { 4. Spreadsheet programs } \\
\text { (Microsoft Excel, etc.) }\end{array}$ & 99 & 6 & 0 \\
\hline $\begin{array}{l}\text { 5. Calendars or planners (Google } \\
\text { Calendar, etc.) }\end{array}$ & 62 & 19 & 24 \\
\hline $\begin{array}{l}\text { 6. Cloud services (Google Disk, } \\
\text { Drop Box, etc.) }\end{array}$ & 61 & 25 & 19 \\
\hline $\begin{array}{l}\text { 7. Data box } \\
\text { 8. Registration database system } \\
\text { (ARUM, Highlander, etc.) }\end{array}$ & 46 & 22 & 37 \\
\hline $\begin{array}{l}\text { 9. Programs for creating presentations } \\
\text { (Microsoft Power Point, etc.) }\end{array}$ & 42 & 8 & 17 \\
\hline
\end{tabular}


Table A6. Cont.

\begin{tabular}{|c|c|c|c|}
\hline $\begin{array}{l}\text { 10. Quick chat applications } \\
\text { (Facebook Messenger, WhatsApp, } \\
\text { ICQ, Skype, etc.) }\end{array}$ & 42 & 41 & 22 \\
\hline 11. Teaching or educational programs & 38 & 27 & 40 \\
\hline $\begin{array}{l}\text { 12. Social networks (Facebook, Twitter, } \\
\text { Instagram, etc.) }\end{array}$ & 37 & 44 & 24 \\
\hline 13. Programs for individual planning & 31 & 15 & 59 \\
\hline
\end{tabular}

Appendix H. Two-Dimensional Analysis Focused on Finding out the Connections between Age, Education, and Length of Practice in Workers of Selected Social Services for Vulnerable Children and Their User Skills (Using an Example of MS Excel Program)

Hypothesis 1 (H1). The age of the worker is related to the level of his/her user skills in working with programs (MS Excel).

First of all, we were interested in the connection between the age of the social worker and the level of his/her user skills in working with various programs (MS Excel). The age variable of the respondents was determined using the open-ended question: "What is your age?" Three age categories emerged: 18-30 years, 31-45 years, and 46-60 years. The variable level of user skills in working with programs (specifically with MS Excel) was determined by following this instruction: "Determine on a scale how you would rate your user skills for each program." The respondents had an opportunity to evaluate their user skills on a five-point scale. The respondents were instructed to grade, as if they were at school, on a scale from 1 to 5 . To evaluate the statistical test, the scales 1 and 2 and the scales 4 and 5 were merged, thus creating a three-point scale-excellent (scale 1 and 2), sufficient (scale 3), and insufficient (scale 4 and 5).

Table A7. The age of the worker and the degree of his/her user skills in working with programs.

\begin{tabular}{ccccc}
\hline \multirow{2}{*}{ The Worker's Age } & \multicolumn{4}{c}{ The Level of User Skills in Working with Programs } \\
\cline { 2 - 5 } & Excellent & Sufficient & Insufficient & In Total \\
\hline $18-30$ let & $26(25 \%)$ & $11(10 \%)$ & $2(2 \%)$ & $39(37 \%)$ \\
\hline $31-45$ let & $27(26 \%)$ & $19(18 \%)$ & $5(5 \%)$ & $51(49 \%)$ \\
\hline $46-60$ let & $6(6 \%)$ & $7(6)$ & $2(2 \%)$ & $15(14 \%)$ \\
\hline
\end{tabular}

Table A7 shows the relative (absolute) frequency of perception of the degree of their user skills in working with programs, specifically with MS Excel, in relation to the age of the workers. We tested H1 statistically, using Pearson's Chi-square. The value of significance was higher in this hypothesis (0.879) than the determined level of significance (0.05), and therefore, we could not reject the null hypothesis. We state that there is no statistically significant relationship between the age of the workers and the level of user skills in working with programs, specifically with MS Excel.

Hypothesis 2 (H2). The qualification of the worker is related to the level of his/her user skills in working with programs (MS Excel).

We were also interested in the connection between the qualification of the worker and the level of his/her user skills in working with programs (MS Excel). The variable qualification of the worker was ascertained by the question "What is your qualification according to Section 110, Act No. 108/2006?" The respondents had the opportunity to choose one of the options offered: the variable level of user skills in working with programs (specifically with MS Excel) was determined in the same way as for H1. 
Table A8. The qualification of the worker and the level of his/her user skills in working with programs.

\begin{tabular}{ccccc}
\hline \multirow{2}{*}{ The Worker's Qualification } & \multicolumn{4}{c}{ The Level of User Skills in Working with Programs } \\
\cline { 2 - 5 } & Excellent & Sufficient & Insufficient & In Total \\
\hline Accredited course & $7(7 \%)$ & $2(2 \%)$ & $1(1 \%)$ & $10(10 \%)$ \\
\hline Higher vocational education & $11(10 \%)$ & $9(9 \%)$ & $2(1 \%)$ & $22(20 \%)$ \\
\hline Higher education & $41(39 \%)$ & $26(25 \%)$ & $6(6 \%)$ & $73(70 \%)$ \\
\hline
\end{tabular}

Table A8 shows the relative (absolute) frequency of perception of the degree of their user skills in working with programs, specifically with MS Excel, in relation to the qualifications of the workers. We tested H2 statistically using Pearson's Chi-square. The value of significance was higher (0.994) for this hypothesis than the determined level of significance (0.05), and therefore, we could not reject the null hypothesis. We found that there is no statistically significant relationship between the qualification of the worker and the level of user skills in working with programs, specifically with MS Excel.

Hypothesis 3 (H3). The length of the worker's practice is related to the level of his/her user skills in working with programs (MS Excel).

Subsequently, we determined the relationship between the length of the worker's practice and the level of his/her user skills in working with programs (MS Excel). The variable length of the worker's practice was determined by the question "What is the length of your practice (in years) in social service during your entire career?" The respondents answered this open question, and subsequently, the following categorizations were created: 0-5 years, 6-10 years, and 11 and more years. The variable level of user skills in working with programs (specifically with MS Excel) was determined in the same way as for $\mathrm{H} 1$.

Table A9. The length of the worker's practice and the degree of his/her user skills in working with programs.

\begin{tabular}{ccccc}
\hline \multirow{2}{*}{ Length of Practice } & \multicolumn{4}{c}{ The Level of User Skills in Working with Programs } \\
\cline { 2 - 5 } & Excellent & Sufficient & Insufficient & In Total \\
\hline $0-5$ let & $32(31 \%)$ & $14(13 \%)$ & $3(3 \%)$ & $49(47 \%)$ \\
\hline $6-10$ let & $13(12 \%)$ & $13(12 \%)$ & $3(3 \%)$ & $29(27 \%)$ \\
\hline 11 and more years & $14(13 \%)$ & $10(10 \%)$ & $3(3 \%)$ & $27(26 \%)$ \\
\hline
\end{tabular}

Table A9 shows the relative (absolute) frequency of perception of the level of the user skills with working with programs, specifically with MS Excel in relation to the length of practice in social services, for the entire career of the workers. We tested H3 statistically using Pearson's Chi-square. The value of significance was higher in this hypothesis (0.897) than the determined level of significance (0.05), and therefore, we could not reject the null hypothesis. We state that there is no statistically significant relationship between the length of the worker's practice and the level of his/her user skills in working with programs, specifically with MS Excel.

\section{References}

1. Hämäläinen, J.; Matikainen, P. Mechanisms and Pedagogical Counterforces of Young People's Social Exclusion: Some Remarks on the Requisites of Social Sustainability. Sustainability 2018, 10, 2166. [CrossRef]

2. Washington, T.L.; Cushing, D.F.; Mackenzie, J.; Buys, L.; Trost, S. Fostering Social Sustainability through Intergenerational Engagement in Australian Neighborhood Parks. Sustainability 2019, 11, 4435. [CrossRef]

3. Eizenberg, E.; Jabareen, Y. Social Sustainability: A New Conceptual Framework. Sustainability 2017, 9, 68. [CrossRef] 
4. ICT. Information and Communication Technologies. Available online: http://uis.unesco.org/en/glossaryterm/information-and-communication-technologies-ict (accessed on 30 August 2020).

5. Eriksen, T.H. Tyranie Okamžiku [Tyranny of the Moment], 3rd ed.; Brno: Doplněk, Czech Republic, 2018; pp. 16-77.

6. Virilio, P. Informatická Bomba [The Information Bomb]; Červený Kostelec: Pavel Mervart, Czech Republic, 2004; pp. 9-98.

7. Wajcman, J.; Dodd, N. (Eds.) The Sociology of Speed: Digital, Organizational, and Social Temporalities; Oxford University Press: Oxford, UK, 2017; pp. 13-54.

8. MPSV. Digitální Gramotnost. Zpráva o Stavu a Výuce Digitální Gramotnosti a Komparace se Zahraničím [MLSA. Digital literacy. A Report on the State and Teaching of Digital Literacy and a Comparison with Abroad]. 2017. Available online: https://www.mpsv.cz/documents/20142/225517/Digitalni_gramotnost___Zprava_o_stavu_a_vyuce_digitalni_gramotnosti_a_komparace_se_zahranicim.pdf/f633dd0f-e5df-c19f7cfa-38291b31ceb4 (accessed on 30 August 2020).

9. Lupač, P.; Chrobáková, A.; Sládek, J. Internet v České Republice 2014 [Internet in the Czech Republic]. Available online: https:/www.worldinternetproject.com/api/file/filemanage/56/Reports/20171009/files/ 35d73bc04851eb77c3bf12d7d860ca16.pdf (accessed on 30 August 2020).

10. Wong, Y.C. Digital Divide Challenges of Children in Low-Income Families: The Case of Shanghai. J. Technol. Hum. Serv. 2015, 33, 53-71. [CrossRef]

11. MSMT. Strategie Digitálního Vzdělávání do Roku 2020. [MSYS. Digital Education Strategy until 2020]. Available online: https://www.msmt.cz/vzdelavani/skolstvi-v-cr/strategie-digitalniho-vzdelavani-do-roku2020 (accessed on 30 August 2020).

12. Friemel, T.N. The digital divide has grown old: Determinants of a digital divide among seniors. New Media Soc. 2014, 18, 313-331. [CrossRef]

13. Vondrová, V. Digitální exkluze: Dimenze sociální exkluze v informační společnosti. [Digital exclusion: Dimensions of social exclusion in the information society]. Soc. Práce/Soc. Práca 2014, 14, 81-101.

14. Recmanová, A.; Vávrová, S. Information and communication technologies in interventions of Czech social workers when dealing with vulnerable children and their families. Eur. J. Soc. Work 2018, 21, 876-888. [CrossRef]

15. Zákon 359/1999 Sb., o sociálně právní ochraně dětí [Act No. 359/1999 Coll., On the Social and Legal Protection of Children]. Available online: https://www.zakonyprolidi.cz/cs/1999-359 (accessed on 30 August 2020).

16. Zákon 108/2006 Sb., o sociálních službách [Act No. 108/2006 Coll., On Social Services]. Available online: https://www.zakonyprolidi.cz/cs/2006-108 (accessed on 30 August 2020).

17. SAS. Sociálně Aktivizační Služby pro Rodiny s Dětmi. [SAS. Social Activation Services for Families with Children.]. Available online: https://spoluprorodinu.cz/sas-ostrava/ (accessed on 30 August 2020).

18. Zákon 110/1998 Sb., o bezpečnosti České republiky [Act No. 110/1998 Coll., On the Security of the Czech Republic]. Available online: https://www.zakonyprolidi.cz/cs/1998-110 (accessed on 30 August 2020).

19. Gitterman, A.; Germain, C.B. The Life Model of Social Work Practice. Advances in Theory and Practice, 3rd ed.; Columbia University Press: New York, NY, USA, 2008; pp. 51-111.

20. Germain, C. Social Work Practice: People and Environments: An Ecological Perspective; Columbia University Press: New York, NY, USA, 1949; pp. 1-45.

21. Payne, M. Modern Social Work Theory, 4th ed.; Oxford University Press: Oxford, UK, 2014; pp. $184-210$.

22. Pillai, V.K.; Gupta, R.; The Greening of Social Work. A Paper Developed for the Council On Social Work Education Global Commission. Available online: https://rc.library.uta.edu/uta-ir/bitstream/handle/10106/ 25841/Greening\%20of\%20Social\%20Work.pdf?sequence=3\&isAllowed=y (accessed on 24 October 2020).

23. Kemp, S.P.; Palinkas, L.A. Strengthening the Social Response to the Human Impacts of Environmental Change. Available online: https://aaswsw.org/wp-content/uploads/2015/03/Social-Work-and-Global-EnvironmentalChange-3.24.15.pdf (accessed on 24 October 2020).

24. Robinson, L.; Cotten, S.R.; Ono, H.; Quan-Haase, A.; Mesch, G.; Chen, W.; Schulz, J.; Hale, T.M.; Stern, M.J. Digital inequalities and why they matter. Inf. Commun. Soc. 2015, 18, 569-582. [CrossRef]

25. Deursen, A.; Dijk, V. The digital divide shifts to differences in usage. New Media Soc. 2013, 16, 507-526. [CrossRef]

26. Elswick, S.E. Informatics in Social Work Practice: Technology within the Field; Nova Science Publishers: Hauppauge, NY, USA, 2017; pp. 18-54. 
27. Peláez, A.L.; Erro-Garcés, A.; Gómez-Ciriano, E.J. Young people, social workers and social work education: The role of digital skills. Soc. Work Educ. 2020, 39, 825-842. [CrossRef]

28. Vávrová, S.; Recmanová, A.; Kowaliková, I.; Gojová, A.; Vaňharová, A. Using ICT in Social Work Focused on E-exclusion Groups. Soc. Behav. Sci. 2019, 370-381. [CrossRef]

29. Mapa Sociálně Vyloučených a Sociálním Vyloučením Ohrožených Romských Lokalit v České Republice. [A Map of Socially Excluded and Socially Endangered Roma Localities in the Czech Republic]. Available online: https://www.esfcr.cz/mapa/int_mors.html (accessed on 30 August 2020).

30. Registr Poskytovatelů Sociálních Služeb. [Register of Social Service Providers]. Available online: http://iregistr.mpsv.cz/socreg/hledani_sluzby.do?sd=sociálně+aktivizační+služby+pro+rodiny+s+dětmi\& zak=\&zaok=\&SUBSESSION_ID=1603615453360_1 (accessed on 24 October 2020).

31. MPSV. Statistická Ročenka z Oblasti Práce a Sociálních Věcí 2018 [MLSA. Statistical Yearbook of Labor and Social Affairs 2018]. Available online: https:/www.mpsv.cz/documents/20142/975025/Statisticka_rocenka_z_ oblasti_prace_a_socialnich_veci_2018+\%282\%29.pdf/d16a5977-62d8-0ce2-bfd4-15d6118a9700 (accessed on 24 October 2020).

32. Zákon 110/2019 Sb., o zapracování osobních údajů [Act No. 110/2019 Coll., On the Processing of Personal Data]. Available online: https://www.zakonyprolidi.cz/cs/2019-110 (accessed on 30 August 2020).

33. Elichová, M. Sociální Práce. Aktuální Otázky [Social Work. Current Issues]; Praha: Grada, Czech Republic, 2017; pp. 127-130.

34. Kelblová, L.; Modráček, Z. Dovednosti České Populace v Prostředí Informačních Technologií, 2014 [Skills of the Czech Population in Information Technologies, 2014]. Available online: https://piaac.cz/attach/PIAAC_ ICT_zprava.pdf (accessed on 24 October 2020).

35. Csiernik, R.; Furze, P.; Dromgole, L.; Rishchynski, G.M. Information Technology and Social Work-The Dark Side or Light Side? J. Evid. Based Soc. Work 2006, 3, 9-25. [CrossRef]

36. Prensky, M. Digital Natives, Digital Immigrants. Horizon 2001, 9, 1-6.

37. Palfrey, J.; Gasser, U. Born Digital: Understanding the First Generation of Digital Natives; Basic Books: New York, NY, USA, 2008; pp. 1-32.

38. Lupač, P. Za Hranice Digitální Propasti. Nerovnost v Informační Společnosti [Beyond the Digital Divide. Inequality in the Information Society]; Sociologické Nakladatelství: Praha, Czech Republic, 2015; pp. 65-170.

39. MZCR. COVID-19 Přehled aktuální situace v ČR. [MHCR. COVID-19 An overview of the current situation in the Czech Republic]. Available online: https://onemocneni-aktualne.mzcr.cz/covid-19 (accessed on 30 August 2020).

40. Hargittai, E. Digital Na(t)ives? Variation in Internet Skills and Uses among Members of the "Net Generation". Sociol. Inq. 2010, 80, 92-113. [CrossRef]

41. Boydová, D. Je to Složitější. Sociální Život Teenagerư na Sociálních Sítích [It's More Complicated. Social Life of Teenagers on Social Networks]; Akropolis: Praha Czech Republic, 2017; pp. 185-238.

42. Livingstone, S.; Bober, M.; Helsper, E.J. Internet Literacy among Children and Young People: Findings from the UK Children Go Online Project; LSE Research Online: London, UK; Available online: http://eprints.lse.ac.uk/ archive/00000397 (accessed on 30 August 2020).

43. Castillo De Mesa, J.; Gómez Jacinto, L.; López Peláez, A.; Palma García, M.D. Building relationships on social networking sites from a social work approach. J. Soc. Work Pract. 2019, 33, 201-215. [CrossRef]

44. Willoughby, M. A review of the risks associated with children and young people's social media use and the implications for social work practice. J. Soc. Work Pract. 2018, 33, 127-140. [CrossRef]

45. Eynon, R. The digital skills paradox: How do digitally excluded youth develop skills to use the internet? Learn. Media Technol. 2016, 41, 463-479. [CrossRef]

46. Schou, J.; Pors, A.S. Digital by default? A qualitative study of exclusion in digitalised welfare. Soc. Policy Adm. 2018, 53, 464-477. [CrossRef]

47. Musil, L. Challenges of Postmodern Institutionalisation for Education in Social Work. In Social Work, Education and Postmodernity. Theory and Studies in Selected Czech, Slovak and Polish Issues; Matulayová, T., Musil, L., Eds.; Technical University of Liberec: Liberec, Czech Republic, 2013; pp. 10-72.

48. Gojová, A.; Gřundělová, B.; Cilečková, K.; Chrenková, M. Path toward a Child-Centered Approach in the Czech Social and Legal Protection of Children. Sustainability 2020, 12, 8897. [CrossRef] 
49. Glumbíková, K.; Vávrová, S.; Nedělníková, D. Optiky posuzování v agendě sociálně-právní ochrany dětí. [Viewpoints of assessment in the agenda of social and legal protection of children.]. Soc. Práce/Soc. Práca 2018, 18, 78-88.

50. Laidlaw, K.; Cabiati, E.; Henriksen, O.; Shore, C. Preparing students for social work practice in contemporary societies: Insights from a transnational research network. Eur. J. Soc. Work 2020, 2020 23, 980-991. [CrossRef]

51. Tøge, A.G.; Malmberg-Heimonen, I.; Liodden, T.; Rugkåsa, M.; Gyüre, K.; Bergheim, B. Improving follow-up with low-income families in Norway. What is new and what is already regular social work practice? Eur. J. Soc. Work 2020, 23, 729-741. [CrossRef]

52. Burton, J.E. Reframing social work practice education: Practice educators' perceptions of the Professional Capabilities Framework (PCF) and the support provided during implementation. J. Soc. Work Pract. 2019, 2019. 34, 39-52. [CrossRef]

53. Skillmark, M.; Oscarsson, L. Applying standardisation tools in social work practice from the perspectives of social workers, managers, and politicians: A Swedish case study. Eur. J. Soc. Work 2018, 23, 365-376. [CrossRef]

54. Wilkerson, D.A. Online psychoeducation with parent management training: Examining the contribution of peer support. Child Fam. Soc. Work 2019, 25, 448-459. [CrossRef]

55. Aguilar-Idañez, M.J.; Caparrós-Civera, N.; Anaut-Bravo, S. E-social work: An empirical analysis of the professional blogosphere in Spain, Portugal, France and Italy. Eur. J. Soc. Work 2018, 23, 80-92. [CrossRef]

56. García-Castilla, F.J.; De-Juanas Oliva, Á.; Vírseda-Sanz, E.; Páez Gallego, J. Educational potential of e-social work: Social work training in Spain. Eur. J. Soc. Work 2018, 22, 897-907. [CrossRef]

57. Chan, C. ICT-Supported Social Work Interventions with Youth: A critical review. J. Soc. Work 2016, 18, 468-488. [CrossRef]

58. West, D.; Health, D. Theoretical Pathways to the Future: Globalization, ICT and Social Work Theory and Practice. J. Soc. Work 2011, 11, 209-221. [CrossRef]

59. Využívání Informačních a Komunikačních Technologií v Domácnostech a Mezi Jednotlivci-2019. Počítače a Internet v Domácnostech. [Use of Information and Communication Technologies in Households and among Individuals-2019. Computers and the Internet in Households]. Available online: https://www.czso.cz/documents/10180/90577057/06200419k01.pdf/34dc31e4-fbe0-4c8280fd-a472c79e989b?version=1.1 (accessed on 24 October 2020).

60. Keller, J. Tři Sociální Světy [Three Social Worlds]; Ostravská Univerzita v Ostravě: Ostrava, Czech Republic, 2010; pp. 13-18.

61. Byrne, J.; Burton, P. Children as Internet users: How can evidence better inform policy debate? J. Cyber Policy 2017, 2, 39-52. [CrossRef]

62. Pentini, A.A.; Lorenz, W. The Corona crisis and the erosion of 'the social' - Giving a decisive voice to the social professions. Eur. J. Soc. Work 2020, 23, 543-553. [CrossRef]

63. Helsper, E.J.; Reisdorf, B.C. The emergence of a "digital underclass" in Great Britain and Sweden: Changing reasons for digital exclusion. New Media Soc. 2016, 19, 1253-1270. [CrossRef]

64. Hämäläinen, J.; Pihlainen, K.; Vornanen, R. Sustainable Family Life and Child Welfare: A Conceptual Framework. Sustainability 2020, 12, 9112. [CrossRef]

Publisher's Note: MDPI stays neutral with regard to jurisdictional claims in published maps and institutional affiliations.

(C) 2020 by the authors. Licensee MDPI, Basel, Switzerland. This article is an open access article distributed under the terms and conditions of the Creative Commons Attribution (CC BY) license (http://creativecommons.org/licenses/by/4.0/). 